\title{
Transitivity Analysis of “Heroic Mother” by Hoa Pham
}

\author{
Hanh Thu Nguyen ${ }^{1}$ \\ ${ }^{1}$ Faculty of Arts, University of Wollongong, New South Wales, Australia \\ Correspondence: Hanh Thu Nguyen, 75/41 Northfields Ave, Gwynneville, NSW, 2500, Australia. Tel: \\ 61-430-611-963. E-mail: thn300@uowmail.edu.au
}

Received: June 7, 2012 Accepted: June 27, 2012 Online Published: July 25, 2012

doi:10.5539/ijel.v2n4p85

URL: http://dx.doi.org/10.5539/ijel.v2n4p85

\begin{abstract}
The paper investigates the application of Halliday's theory of transitivity in the construction of personality. The essay aims to identify and explain how the main character's personality is portrayed and represented through language used in Hoa Pham's "Heroic Mother". The findings hope to prove that linguistic choices in transitivity play an important role in building up the main character of the story.

The essay is divided into six parts. The first part explains the roles of language and language studies in social life. The second part notes the functions of Halliday's transitivity system in literary studies by reviewing previous studies on transitivity. The next part deals with Halliday's theoretical framework of transitivity as a guideline for this analysis. The fourth part introduces Hoa Pham - an Australian Vietnamese writer and playwright, the author of "Heroic Mother". The analysis of transitivity in "Heroic Mother" is provided in the fifth part. The last section of the essay offers concluding remarks about the interpretation of "Heroic Mother". The discussion of results will show how linguistics analysis together with observations about the text enables a better understanding of the main character, known as a "heroic mother".
\end{abstract}

Keywords: transitivity, linguistics, Heroic Mother, personality, literary studies

\section{Introduction}

It is widely believed that people who study and use a language are interested in how they can do things with language, how they can make meanings build up and be understood through choices of words and grammatical resources. Bloor and Bloor claim that "when people use language, their language acts produce - construct meaning” (2004, p. 2). Kroger and Wood (2000, p. 4) believe that language is taken to be not simply a tool for description and a medium of communication but as a social practice, a way of doing things. Gee (2005, p. 10) even claims that "language has a magical property: when we speak or write, we design what we have to say to fit the situation in which we are communicating. But at the same time, how we speak or write creates that very situation." In other words, language shapes and reinforces attitudes and beliefs, then, is a medium for cuing identities, activities, values, and ideologies.

The study of language is so important that, as Fairclough (1989, p. 2) states, "using language is the most common form of social behaviour" and we depend on language in our public and private interaction, determining our relationships with other individuals and the social institutions we inhabit. For Halliday (1985, xiv), "a language is interpreted as a system of meanings, accompanied by forms through which the meanings can be realized and answer the question, "how are these meanings expressed?" This puts the forms of a language in a different perspective: as means to an end, rather than as an end in themselves.” It is from this point of view of language that systemic functional linguistics was developed by Halliday and his associates during the 1960s.

Fairclough claims that language "is a material form of ideology, and language is invested by ideology" (2001, p. 73). Social language or discourse is not only representational but intervenes in social change because "discourse contributes to the creation and recreation of the relations, subjects... and objects which populate the social world" (p. 73). That is to say, discourses are material effects of ideology which also have a strong impact on shaping our sense of reality. Making the same point, Fowler makes the link between discourse and ideology even clearer when he defines discourse as "socially and institutionally originating ideology, encoded in language" (1986, p. 42). Discourse is a way to mould and manifest ideologies, where "ideology" can be defined as the everyday taken for granted collective set of assumptions and value systems that social groups share (Simpson, 1993). 
Moreover, ideologies are the essential and basic social concepts that reflect the aims, significances and values of the social group (Wodak, 2001). Fairclough (2003) also stresses that discourse is a powerful vehicle in the construction of social reality, a vehicle that shapes points of views through dominant ideologies and constructs the realities of living and being. In this sense, discourse is dialectically related to the socio-cultural and institutional contexts. In the words of Fowler, "language provides names of categories, and so helps to set boundaries and relationships and discourse allows these names to be spoken and written frequently, so contributing to the apparent reality and currency of categories” (1986, p. 94). Therefore, language and language study attract a lot of academic researchers from different disciplines to better understand contemporary society.

With this idea in mind, in this paper, I will examine the function of language as powerful social practice in the short story "Heroic Mother" published in 2008 by the Australian Vietnamese writer Hoa Pham in the light of Halliday's theoretical framework on transitivity. The aim is to clarify the main character's personality.

\section{Previous Analysis on Transitivity of Literary Texts}

Transitivity analysis has been widely used to understand the language of speakers and writers. It examines the structure of sentences which are represented by processes, the participants involved in these processes, and the circumstances in which processes and participants are involved. Using transitivity analysis, researchers have tried to reveal that language structures can produce certain meanings and ideology which are not always explicit for readers. In other words, the task of functional analysis, particularly transitivity analysis, is to discover the relation between meanings and wordings that accounts for the organization of linguistic features in a text. Therefore, the concept of transitivity has been used by a number of linguists to shed more light on the use of language in a literary text.

As a pioneer and scholar in transitivity analysis, Halliday's study of William Golding's The Inheritors is an influential example. Carter and Stockwell describe it as "one of the groundbreaking analysis in stylistics" (1971, p. 19). In this analysis, Halliday points out how understanding grammar, especially transitivity, can help interpret the meaning in a literary text. According to Halliday's theory, patterns of transitivity, including processes, participants, and the circumstances, occur in the clauses and sentences of a text. He claims that "transitivity is the set of options whereby the speaker encodes his experience and transitivity is really the cornerstone of the semantic organization of experience" (p. 81).

Following the method of transitivity analysis developed by Halliday, Yaghoobi (2009) makes a systemic analysis of news structures in two selected printed media, namely Newsweek and the Kayhan International. By identifying processes and the role of participants involved in those processes, Yaghoobi's study proves that the representation of the same news actors, Hizbullah and Israeli forces, by two different and ideologically opposed printed media, were opposite to each other.

These transitivity analyses are just a few among many, but they are fundamental examples of how language patterns, particularly transitivity, can convey the meaning and ideology of a literary text. They also add further dimensions that have proved useful in stylistic analysis. The functional grammar analysis of English helps readers understand human interactions in social contexts and can be used to uncover ideological meanings within them. In the next part, the focus will be on explaining the theory of transitivity.

\section{Theory on Transitivity}

The systemic functional linguistics approach to discourse analysis is based on the model of "language as a social semiotic" outlined in the works of Halliday. Language is used functionally, what is said depends on what one needs to accomplish. In Halliday's theory, language expresses three main kinds of meanings simultaneously: ideational, interpersonal, and textual meanings (1985). Among them, the ideational meaning (the clause as representation) serves for the expression of "content" in language, that is, our experience of the real world, including the experience of our inner world. When we use language we often use it to speak of something or someone doing something. That is why the ideational meaning can be referred to as experiential meaning coming from the clause as representation.

The interpersonal meaning helps to establish and maintain social relations; the individual is identified and reinforced in this aspect by enabling him/her to interact with others by expression of their own individuality. Our role relationships with other people and our attitudes towards others are often expressed by interpersonal meaning. This line of meaning in a clause comes from the clause serving as an exchange. We usually use language to facilitate an action or to demand an object and the expectant result is most generally gained verbally or in writing. 
The textual meaning creates links between features of the text with elements in the context of situation; it refers to the manner in which a text is organized. In other words, the textual meaning comes from the clause as message. The clause gets its meaning/massage from its thematic structure. Halliday and Matthiesen defines the theme of clause as a "starting point of the message: it is what the clause is going to be about" (1976, p. 64). With that, the theme serves to locate and orientate the clause within the context. The other part of the message that extends and elaborates the theme is the rheme. Therefore, a clause consists of both a theme and a rheme and a theme + rheme combination will give a precise illustration on the text orientation, its ideas and subject matters.

Halliday also claims that the three types of meanings presented in language are not accidental but are necessarily in place because we need them to perform functions in social life.

In constructing experiential meaning, there is one major system of grammatical choice involved: the system of transitivity or process type. I have chosen transitivity because of all the grammatical aspects analysed, it produces the fruitful data on the text. In his An Introduction to Functional Grammar, Halliday identifies transitivity as follows:

A fundamental property of language is that it enables human beings to build a mental picture of reality, to make sense of their experience of what goes on around them and inside them. ...Our most powerful conception of reality is that it consists of "goings-on": of doing, happening, feeling, being. These goings-on are sorted out in the semantic system of language, and expressed through the grammar of the clause... This... is the system of TRANSITIVITY. Transitivity specifies the different types of processes that are recognised in the language and the structures by which they are expressed (1985, p. 101)

The theoretical framework of transitivity was established and developed by Halliday. Transitivity generally refers to how meaning is represented in clauses; transitivity patterns can reveal the certain worldview "framed by the authorial ideology" in a literary text (Fowler, 1986, p. 138). Clauses represent events and processes of various kinds, and transitivity aims to make clear how the action is performed, by whom and on what. Transitivity is an important and powerful semantic concept in Halliday. It is part of the ideational function of language, therefore, an essential tool in the analysis of representation. Implicitly and crucially, different social structures and values require different patterns of transitivity.

While Kress (1976, p. 169) states that transitivity is representation in language processes, Simpson asserts that transitivity refers generally to how meaning is represented in the clause (1993, p. 88). Hasan claims that transitivity:

... is concerned with a coding of the goings on: who does what in relation to whom/what, where, when, how, and why. Thus the analysis is in terms of some process, its participants, and the circumstances pertinent to the process - participant configuration. (1988, p. 63)

In other words, transitivity can show how speakers/writers encode in language their mental reflection of the world and how they account for their experience of the world around them.

Halliday's theory that transitivity is measurable will be used to study the clausal structure which is based on the main verb of the sentence. According to this theory, in transitivity different processes are distinguished according to whether they represent actions, speech, states of mind or states of being. Those are identified, classified and known as Material processes, Relational processes, and Mental processes.

Material processes of transitivity are processes of doing, usually physical and tangible actions. Halliday calls them action clauses expressing the fact that something or someone undertakes some action or some entity "does" something - which may be done to some other entity. These processes can be probed by asking what did $x$ do? Two essential participants usually appear in material process are the Actor - the doer of the process - and the Goal - the person or entity affected by the process.

Mental processes usually encode mental reactions such as perception, thoughts and feelings. Mental processes give an insight into people's consciousness and how they sense the experience of the reality. These can be probed by asking what do you think/ feel/know about $x$ ? Mental processes have two participants: the Senser - the conscious being who is involved in a Mental process - and the Phenomenon - which is felt, thought, or seen by the conscious Senser.

Relational processes construe the relationships of being and having between two participants. There are two different types of Relational processes; one is called Identifying Relational which serves the purpose of defining and the participants involved are Token and Value. Thus the Value serves to define the identity of the Token. The other type of Relational process is the attributive Relational which serves to describe. The participants associated 
with it are the Carrier and the Attribute and we can say that "the $\mathrm{x}$ (realized by Carrier) is a member of the class $\mathrm{y}$ (realized by Attribute)".

There are also three subsidiary process types that share the characteristic features of each of the three main processes. Between Material and Mental processes lie Behavioural processes that characterize the outer expression of inner working and reflect physiological and psychological behaviours such as breathing, laughing, sneezing... Behavioural processes usually have one participant who is typically a conscious one, called the Behaver. Between Mental and Relational processes are Verbal processes, which represent the art of saying and its synonyms. Usually three participants are involved in Verbal processes: the Sayer is responsible for verbal process; the Receiver is the person at whom the verbal process is directed; and the Verbiage is the nominalised statement of the verbal process. And between Relational and Material processes are Existential processes which prove states of being, existing, and happening. Existential processes typically employ the verb be or its synonyms such as exist, arise, occur. The only participant in this process is Existent which follows the there is /are sequences.

Table 1. Examples of different process types from "Heroic Mother"

\begin{tabular}{|c|c|}
\hline Process Type & 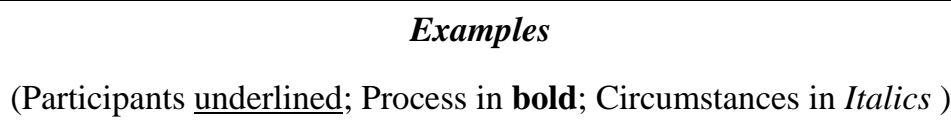 \\
\hline Material & I do my exercise near Hoan Kiem lake \\
\hline Behavioural & $\underline{I}$ smile at them \\
\hline Mental & $\underline{\text { I do not understand }}$ \\
\hline Verbal & They say ->I have acted crazy all my life \\
\hline Relational & I am a kindly grandmother \\
\hline Existential & today there's Christianity in the south (Note 1 ) \\
\hline
\end{tabular}

There is no priority of one process type over another so Halliday and Matthiessen portray the interrelationship between transitivity processes as a sphere which enables us to construe and portray our experiential meanings of the world, how we perceive what is going on (1976, p. 172). Transitivity processes are also useful in uncovering the participants involved, how the speaker/writer locate himself in relation to the others, and whether they take an active or passive role in the communication.

After examining the transitivity and its processes from Halliday's systemic functional grammar, I will proceed to analyse the data. My focus is not on linguistic or stylistic patterns, but on checking how these linguistic patterns are used to define characters and meanings.

\section{Introduction to the Author (Note 2)}

Hoa Pham's "Heroic Mother" is a short story which was published in 2008. Hoa Pham is an Australian Vietnamese author and playwright. I am taking this biographical information from her website, so I hope it is correct. She was awarded the 2001 Sydney Morning Herald's Young Writer of the Year for her novel Vixen. Currently, she is the editor of Peril, an online journal of arts and culture for Asian Australians. She has already published two novels, namely Quicksilver and Vixen, several children's books including No-one Like Me and 49 Ghosts, short stories "Reality", "Yolk", and "Heroic Mother", and more recently, two plays Silence and I could be you.

Though Hoa Pham has received recognition in the field, there is a lack of academic criticism on her work. This is partly because of the fact that she is an up and coming writer. In spite of this fact, I have decided to go for this writer in order to move away from particular Asian Australian writers whose works have been over-studied. I chose her work because I wanted to look at a text that had not yet been studied by critics.

\section{Adaptation of Transitivity Aanalysis in "Heroic Mother"}

Hoa Pham's "Heroic Mother" describes the locked-in solitude of the elderly who often talk about their past memories and victories as a way to educate younger generations. This short story also depicts the spiritual and emotional gaps between the elderly and their children who often care more about the outside world or their personal interests than family relations. 
"Heroic Mother" is a first-person narrative in which the main character acts as the narrator and speaks in such a way as to refer to herself, providing an account of events from "inner" points of view. This gives the advantage of sympathy to the character and helps readers get the character's thoughts and feelings in an intimate way.

The first sentence of the story gives a comment on the main character as "a little crazy" person. She is living with her family in Hanoi, the capital city of Vietnam. She is considered an absent-minded elderly lady with conservative feelings and behaviours. What is more, she seems to be neglected and ignored by her relatives. As one part of her story-telling, the main character retells her past to prove that she is not crazy; she just "acted crazy" to disguise herself in resistance and fighting the war. Several details about the neighbourhood and the companions of the main character are also provided.

Before analysing the text, I should note that transitivity analysis requires that complex sentences in the text be cut into simple clauses involving a process and the participants in the process. The clauses are numbered in order of the story. Though the analysis covers the whole story, to make it easier for analysis I have divided the story into three parts to represent the changes and developments in the main character's thoughts and feelings (see Appendix A). The following is the examination of language which leads to the above interpretations of "Heroic Mother”.

\subsection{Part 1}

To begin with, we should look into the frequency and the role of the main character as a participant in the processes assigned to her. Of 25 participants in the first part, only 6 refer to the main character herself (clause $1 \mathrm{~b}$, 3a, 3b, 3c, 3e, 5a) while 5 refer to the co-operation of the main character with the other family members or friends (clause $1 \mathrm{a}, 5 \mathrm{~b}, 6 \mathrm{~b}, 7 \mathrm{a}, 7 \mathrm{~b})$. The other 14 participants are the city or the environment such as "the locals", "the kids", "the green of the lake", and "the traffic" (Note 3)... This suggests that the main character does not take a central role as participant even though she is introduced right from the first sentence of the story. It seems that, by focusing on the city and the environment, the writer invites readers to join the main character's society where she is living so that they can have a better understanding of her.

In term of process type, among 11 processes with the main character's involvement, 6 are carried out by her while 5 are taken by her together with other people. In those 6 processes, 5 are either Relational processes (2-clause 1b, 3e), or Behavioural processes (2-clause 3a, 3b), or Mental processes (1-clause 3c), whereas only one takes a Material process (clause 5a). The much greater proportion of Relational, Behavioural and Mental processes to Material processes illustrates that the narrator, also the main character, tries to sketch her relationship, behaviour and her inner thoughts towards other members of her family or towards life and society as in the examples of "smile" or "do not understand". With only one Material process assigned, as in "...I do exercise in Hoan Kiem lake...", she becomes an Actor but her action does not affect anyone else, not even her relatives, because the Goal in this process is "exercise". Therefore, it could be argued that, as an elderly lady, she is not supposed to or perhaps she is not strong enough to get involved in any activities except taking care of herself by "doing [her] exercise" every morning.

Among 25 processes in this part, there is only one Verbal process (clause 2a) in which the family members take the role of Sayer. However, it is not the conversation between the family members and their grandma because the Verbiage is the statement that "[she] is a little crazy". Sadly enough, though she lives with her family, there is no interaction between them. The children usually avoid having talks with her by "zooming off on their nice new mopeds" or they "turn on the TV and watch their cartoon American movies". The children, including her granddaughter, tend to ignore her.

Though being thought as a "little crazy" grandma in the family, the main character still pays great concern to other members, especially to her granddaughter. The next section reveals how she cares for her relatives.

\subsection{Part 2}

In discussing part two, I will focus first on the representation of process type. Eight processes assigned to the main character are of 3 types: Mental processes (3-clause 10b, 23a, 23c), Verbal processes (3-clause 10a, 11a, 15c) and Material process (1- clause 16b) (Note 4).

The prevalence of Mental and Verbal processes in this part proves that the main character does not just keep her concerns inside her heart and does nothing. Instead, she with other "older generation" members including parents and friends try to give advice or guidance to her granddaughter as seen in clauses 10a, 11a, 15c. She usually "tells about the good and the future" or "keeps telling [her granddaughter] the good schools and university is in Hanoi". One Material process where she takes the role of Actor involves the Goal of what she and others "have struggled for". This representation of material process suggests that the main character also wants to raise the 
grand daughter's awareness of what is good and what is bad by mentioning the times she and the girl's parents experienced or how they "struggled" for a better future. It is the same with Relational processes, which prove that the main character even tries to share several hobbies with her granddaughter by "watching American movies” but it does not help much to make their relationship closer or friendlier.

Of 32 participants in the whole text, 13 refer to the main character's relatives; of these, 11 refer to her granddaughter. This suggests that as a narrator, the main character is more interested in talking about her granddaughter than herself or other things such as "Hanoi", "school”, "university" or "the persons". She "hopes that her granddaughter does not see what [she] and her parents have seen". As the memories flow, she continues to flash back to her unforgettable past, which may not be easily felt and sympathized with by the younger generations.

The next section examines the concluding part of the story, which reveals more about the main character's past and present days as a grandmother.

\subsection{Part 3}

It is interesting that in this part the main character is the dominant participant in 38 processes out of 62 , or $61 \%$. In the two previous parts, she performs sometimes as a sole participant ("I"), sometimes as a co-participant with her relatives or friends ("We") whereas in this final section, she almost always appears as a sole participant " $I$ " (only in clause 36 as "We") (Note 5). Obviously, she is not only the main character but the narrator of the story. Talking about herself, she tries to explain why she "was not as mad as people said [she] was".

The main character is the participant in 7 Mental processes (clause 24a, 31a, 31c, 34b, 35b, 37b, 43a), 10 Relational processes (clause 24e, 24g, 25a, 27b, 32a, 33a, 33b, 46b, 47b, 50), one Verbal process (clause 51b), and up to 15 Material processes. The much greater use of Material process in this part shows the main character's active involvement in the past, ostensibly a contrast to her position on the sidelines in the present activities. In the past, she "[enacted] out the great epics of the Trung sisters and King Le Loi ", or "would go round the American solders", or "[stood] in the rain", or "[carried] documents". But even in the present, she is surely not a weak elderly grandma for she can "chop meat with a cleaver". She is even smart enough to "choose what [she] can hear and say", which proves that she is "a kindly grandmother" and she can be herself.

In the Relational processes, the main character is the Carrier of the Attribute "mad", "crazy", or "scared" as seen in clauses 24g, 27b, 32a. By using these she wants to stress the stereotype through which she is seen by her relatives. However, in the other example of relational process (clause 33a) the main character portrays herself as being “ $a$ kindly grandmother". That is the way she defends herself against her relatives' misjudgement and their inappropriate attitudes towards her. What is more, by stating her quality of being "kindly" she may believe that it is more important to be herself than to mind the words of others.

Out of 4 Verbal processes in the part 3, the main character's family and daughter take the role of Sayer in 3 Verbal processes as shown in clauses 24f, 42a, 46a. Once more, it is not the verbal interaction between the family and the main character but it is the family's comments on her as being crazy or "acted crazy all [her] life". As they cannot understand what goes on in her mind, they either "tell her off impatiently" or "tell her to shut up".

\section{Conclusion}

Transitivity analysis gives more detailed and more nuanced support to the reader's responses to "Heroic Mother". It provides linguistic evidence to support the interpretation of the story so readers, having been shown on what/who does what to whom/what in the main character's world, are better equipped to decide on the story's meaning.

The study of transitivity through the analysis of processes and the participants involved in these processes shows that the main character, known as a heroic mother, is suffering from the loneliness, boredom, and inadequate consideration from her family. The main character in Hoa Pham's "Heroic Mother” is just an example of what is happening to many so-called heroic mothers who usually live with their sorrows and their victories which are sometimes ignored by younger generations. Though the concept of “heroic mother” is myth, in Barthes' sense of the word, which supports the old women who lost their children during war time, the main character herself in this story experienced the difficult days of her youth. She used to be a soldier or fighter. She accepted being stereotyped as crazy to achieve her cause of a better future.

As with many other heroic mothers during the war, she devoted her energy, her youth, and even her life to the country's independence and freedom. Her silent contribution towards national liberation is an eternal sacrifice. However, as the time goes by, many heroic mothers have passed away while others who survive are facing their old age. These white-with-age survivors usually tell the stories about their lives and their contribution made for the 
country and its people. They consider it a good way to remind younger generations of their past victory as well as to educate them about the sacrifice and patriotism for the national liberation cause. Unfortunately, the younger generation do not always appreciate those educational stories. Some of them even take the present beautiful life for granted, and ignore all the sacrifice and devotion of their elders. Therefore, in "Heroic Mother", the eponymous character is usually seen as having been crazy or "have acted crazy all [her] life" though she herself believes that she "has islands of sanity amongst [her] craziness". Implicitly, as the narrator of the story, the main character wants to tell the readers that "Hey, people don't understand me. I behaved like this just to play my role and to fight the war. I am not crazy at all."

In conclusion, linguistically, I hope this study will contribute towards an understanding how linguistic analysis of a text can be used to interpret meanings in a literary text. In the social extent, this study aims to call people's awareness to the contemporary situation of "heroic mothers". Hopefully, in the future, the concept of "heroic mother" is not just the creation of the title but a much more practical system.

\section{Acknowledgements}

I sincerely thank Professor Leigh Dale for the guidance and support during my writing of this paper. I am also grateful to Dr. Dorothy Jones for her encouragement. Many thanks also go to my friends and family.

\section{References}

Bloor, T., \& Bloor, M. (2004). The Functional Analysis of English (2nd ed.). London: Arnold.

Brooks, J. (2009-2010). The Growing Absurdity of the South African Apartheid: Transitivity in Christopher Van Wyk’s “In Detention”. Innervate-Leading Undergraduate Work in English studies, 2(2009-2010), 26-34.

Burton, D. (1996). Through Glass Darkly: Through Dark Glasses (on Stylistic and Political Commitment - Via a Study of a Passage from Sylvia Plath's the Bell Jar). Stylistics Reader: From Roman Jakobson to the Present, 224-240. New York: St Martin's Press.

Carter, R. (1982). Language and Literature. London: Routledge.

Carter, R., \& Stockwell, P. (2008). The Language and Literature Reader. London: Routledge.

Fairclough, N. (1989). Language and Power. New York: Longman Group UK Limited.

Fairclough, N. (2001). Critical Discourse Analysis as a Method in Social Scientific Research. In Wodak, R., \& Meyer, M. (Eds), Methods of Critical Discourse Analysis (pp. 121-138). London: Sage Publications. http://dx.doi.org/10.4135/9780857028020.d8

Fairclough, N. (2003). Analysing Discourse: Textual Analysis for Social Research. London: Routledge Taylor \& Francis Group.

Fowler, R. (1986). Linguistic Criticism. Oxford: Oxford University Press.

Gee, J. P. (2005). An Introduction to Discourse Analysis: Theory and Method. London: Routledge.

Halliday, M. A. K. (1971). Linguistic Function and Literary Style: An Inquiry into the Language of William Golding's the Inheritors. In Chatman, S. (Ed.), Literary Style: A Symposium (pp. 330-368). New York: Oxford University Press.

Halliday, A. K. (1985). An Introduction to Functional Grammar (2nd ed.). London, Melbourne, Auckland: Edward Arnold.

Halliday, M. A. K., \& Hasan, R. (1985). Language, Context, and Text: Aspects of Language in a Social-Semiotic Perspective. Victoria: Deakin University Press.

Halliday, M. A. K., \& Matthiessen, C. M. (2004). An Introduction to Functional Grammar (3rd ed.). London: Arnold.

Hasan, R. (1988). The Analysis of One Poem: Theoretical Issues in Practice. In Birch, D., \& O’Tool, M. (Eds.), Functions and Styles (pp. 45-73). London: Edward Arnold.

Kress, G. (Ed.). (1976). Halliday: System and Function in Language: Selected Papers. London: Oxford University Press.

Kroger, R. O., \& Wood, L. A. (2000). Doing Discourse Analysis: Method for Studying Action in Talk and Text. California: Sage Publications, Inc.

Lester, M. (1969). The Relation of Linguistics to Literature. JSTOR: College English, 30(5), 366-370. 
Schwartz, E. (1970). Notes on Linguistics and Literature. JSTOR: College English, 32(2), 184-190. http://dx.doi.org/10.2307/374644

Simpson, P. (1993). Language, Ideology and Point of View. New York: Routledge. http://dx.doi.org/10.4324/9780203312612

Thompson, G. (2004). Introducing Functional Grammar. New York: Oxford University Press.

Wodak, R. (2001). What CDA Is About - a Summary of Its History, Important Concepts and Its Development. In Ruth Wodak, \& Michael Meyer (Eds.), Methods of Critical Discourse Analysis (pp. 1-13). London: SAGE.

Yaghoobi, M. (2009). A Critical Discourse Analysis of the Selected Iranian and American Printed Media on the Representation of Hizbullah-Isreal War. Journal of Intercultural Communication, 21.

\section{Appendixes}

Appendix A. Clause listing of "Heroic Mother"

Part 1.

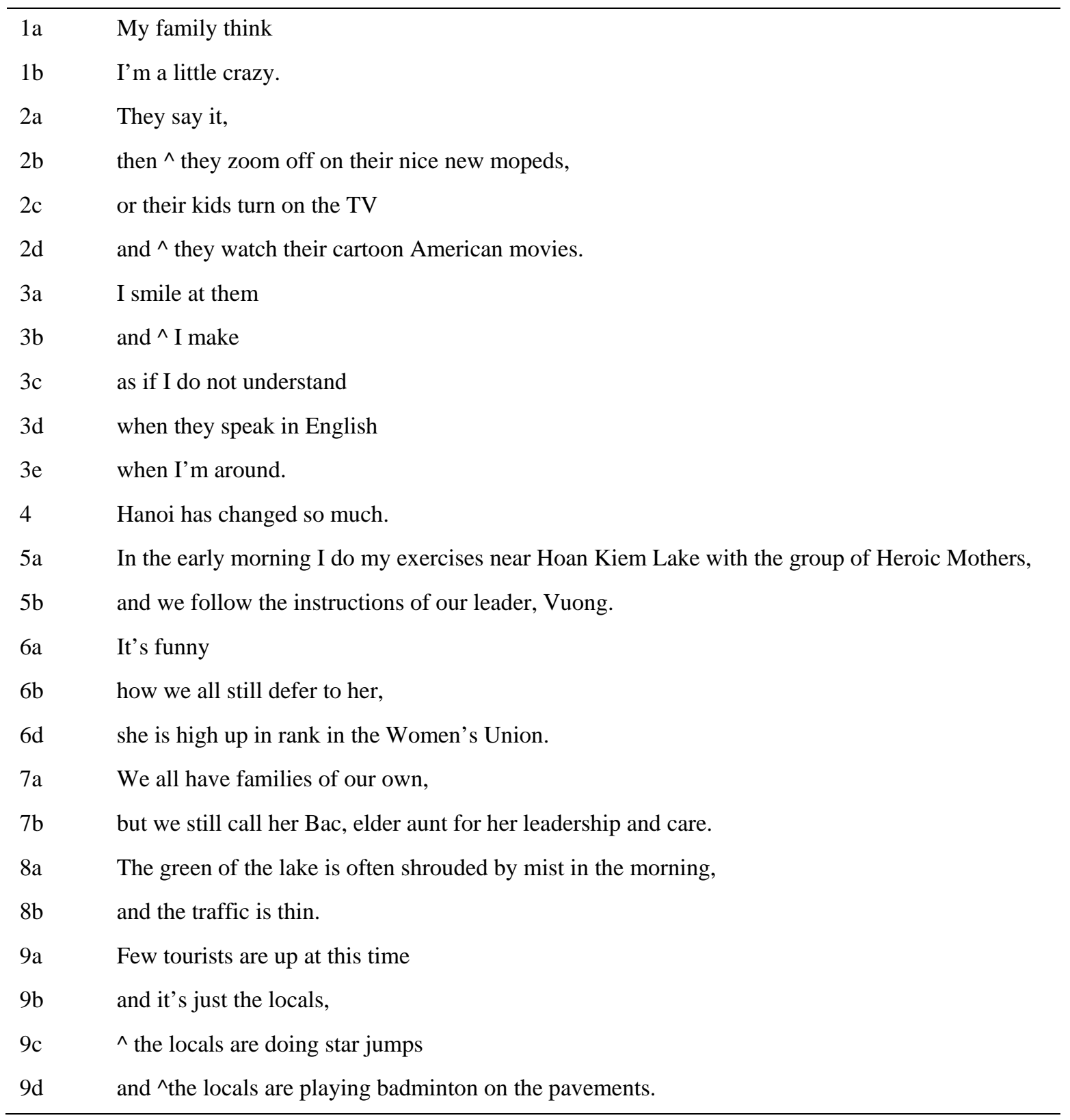


Part 2.

\begin{tabular}{|c|c|}
\hline $10 \mathrm{a}$ & We don't talk about the war \\
\hline 10b & and what we've seen amongst the Heroic Mothers. \\
\hline $11 \mathrm{a}$ & Instead we talk about the good and the future, \\
\hline $11 b$ & what our sons and daughters are doing- \\
\hline 11c & and often how affluent and modern they are. \\
\hline 12 & My granddaughter is a little upstart. \\
\hline $13 \mathrm{a}$ & She calls me Ba \\
\hline $13 \mathrm{~b}$ & and $\wedge$ she was the sweetest thing \\
\hline $13 c$ & when she was younger. \\
\hline $14 \mathrm{a}$ & She’s now hit her teenage years \\
\hline $14 \mathrm{~b}$ & and $\wedge$ she wants to go study in Saigon. \\
\hline $15 \mathrm{a}$ & Hanoi is boring \\
\hline $15 b$ & she says \\
\hline $15 c$ & - even though we keep telling her \\
\hline $15 d$ & the best schools and university is in Hanoi. \\
\hline $16 a$ & She takes for granted \\
\hline $16 b$ & what we had struggled for all along, through the war and doi moi. \\
\hline $17 \mathrm{a}$ & She even leaves food on her plate \\
\hline $17 \mathrm{~b}$ & and $\wedge$ she doesn’t finish her meals. \\
\hline $18 \mathrm{a}$ & When I watch American movies with my grandchildren \\
\hline $18 b$ & it is like fantasy. \\
\hline 19a & When they shoot \\
\hline $19 b$ & the guns don't recoil, \\
\hline 19c & you cannot smell the hot iron, the blood, the burning flesh. \\
\hline $20 \mathrm{a}$ & People just drop dead, \\
\hline 20b & they do not continue surviving against the odds, writhing in pain. \\
\hline 21 & And the prisons are so clean. \\
\hline $22 \mathrm{a}$ & Not like the rat boxes they kept us in \\
\hline $22 b$ & when they caught us spying for the other side. \\
\hline $23 a$ & I hope \\
\hline $23 b$ & that my granddaughter does not see \\
\hline $23 c$ & what I and her parents have seen. \\
\hline
\end{tabular}


Part 3.

\begin{tabular}{|c|c|}
\hline $24 a$ & I remember \\
\hline $24 \mathrm{~b}$ & how relieved my son in law was \\
\hline $24 \mathrm{c}$ & when he married into our family \\
\hline $24 d$ & and $\wedge$ he discovered \\
\hline $24 \mathrm{e}$ & I wasn't as mad as \\
\hline $24 f$ & people said \\
\hline $24 \mathrm{~g}$ & I was. \\
\hline $25 a$ & I acted crazy during the entire war, \\
\hline $25 b$ & $\wedge$ I was wearing the same shirt and indigo pants no matter what the weather, \\
\hline $25 c$ & $\wedge$ I was standing outside in the rain and the sweltering heat \\
\hline $25 \mathrm{~d}$ & $\wedge$ I was enacting out the great epics of the Trung sisters and King Le Loi. \\
\hline $26 a$ & I would go around the American soldiers \\
\hline $26 b$ & $\wedge$ I was begging for money \\
\hline $26 c$ & and $\wedge$ I was singing to them off key and off tempo. \\
\hline $27 a$ & Everyone thought \\
\hline $27 \mathrm{~b}$ & I was crazy except my comrades at the National Liberation Front. \\
\hline $28 \mathrm{a}$ & They knew \\
\hline $28 \mathrm{~b}$ & I was carrying documents for them, in my pockets close to my skin. \\
\hline 29a & I did not bathe, \\
\hline $29 b$ & I stank \\
\hline 29c & so no one would want to go near me. \\
\hline 30 & Sometimes it was fun acting crazy. \\
\hline $31 \mathrm{a}$ & Sometimes I thought \\
\hline $31 b$ & I would go crazy \\
\hline $31 \mathrm{c}$ & when I saw the bodies of my sisters, \\
\hline $31 d$ & $\wedge$ the sisters were raped and tortured by the Imperial puppet forces. \\
\hline 32a & Sometimes I was so scared \\
\hline $32 b$ & acting crazy was my only escape. \\
\hline 33a & Nowadays I am a kindly grandmother \\
\hline $33 b$ & and I can be myself, silver haired and slightly senile. \\
\hline $34 \mathrm{a}$ & I choose \\
\hline $34 \mathrm{~b}$ & what I hear and say. \\
\hline $35 \mathrm{a}$ & I chop meat with a cleaver ignoring the thunks in my head \\
\hline
\end{tabular}


35b when I sometimes flashback to seeing the bodies of corpses splayed open, blood and bone.

$36 \quad$ We are all blood and bone in the end.

37a Sometimes at night I wake up

37b and $\wedge$ I find myself downstairs.

$38 \quad$ My daughter would be holding my hand telling me to shut up.

39 "You are acting crazy again.

$40 \wedge$ You are Remembering the war again.

$41 \quad$ It's over."

42a She would tell me off impatiently

$42 \mathrm{~b}$ when it happened too often.

43a Then I see the TV news

$43 \mathrm{~b}$ and $\wedge$ I try

43c and $\wedge$ I look away.

$44 \quad$ More wars.

45a The Americans are installing more puppet forces.

45b $\wedge$ who are invading Iraq

46a They say

46b I've acted crazy all my life.

47a At least I don't start wars,

47b the only war I had

47c $\wedge$ which was in my heart

47d when killings would occur

47e $\quad$ and $\wedge$ I disguised as a crazy woman

47f all I could do

47g $\wedge$ all was sing louder.

48 I could never drown out the sounds of screaming and the firing of weapons.

49 Even the beat of the bass sounds of my children's music sometimes reminds me of the thumping of artillery.

50 But at least I have islands of sanity amongst my craziness.

51a That's more than

51b what I can say about the world. 
Appendix B. Participants and process types in part 1 of "Heroic Mother"

\begin{tabular}{|c|c|c|c|}
\hline Clause No & Participants & & cess \\
\hline $1 \mathrm{a}$ & My family & think & Mental process \\
\hline $1 b$ & I & $\mathrm{am}$ & Relational process \\
\hline $2 \mathrm{a}$ & They & say & Verbal process \\
\hline $2 b$ & they & zoom off & Material process \\
\hline $2 c$ & their kids & turn on & Material process \\
\hline $2 \mathrm{~d}$ & they & watch & Behavioural process \\
\hline За & I & smile & Behavioural process \\
\hline $3 b$ & I & make & Behavioural process \\
\hline $3 c$ & I & do not understand & Mental process \\
\hline $3 d$ & they & speak & Behavioural process \\
\hline Зe & I & $\mathrm{am}$ & Relational process \\
\hline 4 & Hanoi & has changed & Material process \\
\hline $5 a$ & I & do & Material process \\
\hline $5 b$ & we & follow & Material process \\
\hline $6 a$ & It & is & Relational process \\
\hline $6 b$ & we & defer & Material process \\
\hline $6 d$ & she & is & Relational process \\
\hline $7 \mathrm{a}$ & We & have & Relational process \\
\hline $7 b$ & we & call & Relational process \\
\hline $8 a$ & The green of the lake & is shrouded & Material process \\
\hline $8 b$ & the traffic & is & Relational process \\
\hline $9 a$ & Few tourists & are & Relational process \\
\hline $9 b$ & it & is & Relational process \\
\hline $9 c$ & the locals & are doing & Material process \\
\hline $9 d$ & the locals & are playing & Material process \\
\hline
\end{tabular}


Appendix C. Participants and process types in part 2 of "Heroic Mother"

\begin{tabular}{|c|c|c|c|}
\hline \multirow{2}{*}{$\begin{array}{l}\text { Clause No } \\
10 \mathrm{a}\end{array}$} & \multirow{2}{*}{$\begin{array}{l}\text { Participants } \\
\mathrm{We}\end{array}$} & \multicolumn{2}{|c|}{ Process } \\
\hline & & don't talk & Verbal process \\
\hline 10b & we & have seen & Mental process \\
\hline $11 \mathrm{a}$ & we & talk & Verbal process \\
\hline $11 b$ & our sons and daughters & are doing & Material process \\
\hline 11c & they & are & Relational process \\
\hline 12 & My grand daughter & is & Relational process \\
\hline 13a & She & calls & Relational process \\
\hline $13 b$ & she & was & Relational process \\
\hline $13 c$ & she & was & Relational process \\
\hline $14 \mathrm{a}$ & She & is & Relational process \\
\hline $14 \mathrm{~b}$ & she & wants to go & Material process \\
\hline $15 \mathrm{a}$ & Hanoi & is & Relational process \\
\hline $15 b$ & she & says & Verbal process \\
\hline $15 c$ & we & keep telling & Verbal process \\
\hline $15 d$ & the best schools and university & is & Relational process \\
\hline $16 a$ & She & takes for granted & Material process \\
\hline $16 b$ & we & had struggled & Material process \\
\hline $17 \mathrm{a}$ & She & leaves & Material process \\
\hline $17 b$ & she & doesn't finish & Material process \\
\hline $18 \mathrm{a}$ & I & watch & Behavioural process \\
\hline $18 b$ & it & is & Relational process \\
\hline 19a & they & shoot & Material process \\
\hline $19 b$ & the guns & don’t recoil & Material process \\
\hline 19c & you & cannot smell & Mental process \\
\hline 20a & People & drop & Relational process \\
\hline 20b & they & do not continue & Material process \\
\hline 21 & the prisons & are & Relational process \\
\hline $22 \mathrm{a}$ & they & kept & Material process \\
\hline $22 b$ & they & caught & Material process \\
\hline $23 a$ & I & hope & Mental process \\
\hline $23 b$ & my grand daughter & does not see & Mental process \\
\hline $23 c$ & I and her parents & have seen. & Mental process \\
\hline
\end{tabular}


Appendix D. Participants and process types in part 3 of "Heroic Mother"

\begin{tabular}{|c|c|c|c|}
\hline \multirow{2}{*}{$\begin{array}{l}\text { Clause No } \\
24 a\end{array}$} & \multirow{2}{*}{$\begin{array}{l}\text { Participants } \\
\text { I }\end{array}$} & \multicolumn{2}{|c|}{ Process } \\
\hline & & remember & Mental process \\
\hline $24 \mathrm{~b}$ & my son & was & Relational process \\
\hline $24 c$ & he & married & Material process \\
\hline $24 d$ & he & discovered & Material process \\
\hline $24 \mathrm{e}$ & I & wasn’t & Relational process \\
\hline $24 f$ & people & said & Verbal process \\
\hline $24 \mathrm{~g}$ & I & was & Relational process \\
\hline $25 a$ & I & acted & Relational process \\
\hline 25b & I & was wearing & Material process \\
\hline $25 c$ & I & was standing & Material process \\
\hline $25 d$ & I & was enacting & Material process \\
\hline 26a & I & would go & Material process \\
\hline 26b & I & was begging & Behavioural process \\
\hline $26 c$ & I & was singing & Behavioural process \\
\hline $27 \mathrm{a}$ & Everyone & thought & Mental process \\
\hline $27 \mathrm{~b}$ & I & was & Relational process \\
\hline 28a & They & knew & Mental process \\
\hline 28b & I & was carrying & Material process \\
\hline 29a & I & did not bathe & Material process \\
\hline $29 b$ & I & stank & Material process \\
\hline 29c & no one & would want to go & Material process \\
\hline 30 & it & was & Relational process \\
\hline 31a & I & thought & Mental process \\
\hline $31 b$ & I & would go & Material process \\
\hline 31c & I & saw & Mental process \\
\hline $31 d$ & the sisters & were raped and tortured & Material process \\
\hline 32a & I & was & Relational process \\
\hline $32 b$ & acting crazy & was & Relational process \\
\hline 33a & I & am & Relational process \\
\hline 33b & I & can be & Relational process \\
\hline 34a & I & choose & Material process \\
\hline $34 b$ & I & hear & Mental process \\
\hline
\end{tabular}




\begin{tabular}{|c|c|c|c|}
\hline $35 \mathrm{a}$ & I & chop & Material process \\
\hline $35 b$ & I & flashback & Mental process \\
\hline 36 & We & are & Relational process \\
\hline $37 a$ & I & wake up & Material process \\
\hline $37 b$ & I & find & Mental process \\
\hline 38 & My daughter & would be holding & Material process \\
\hline 39 & You & are acting & Relational process \\
\hline 40 & You & are remembering & Mental process \\
\hline 41 & It & is & Relational process \\
\hline $42 \mathrm{a}$ & She & would tell... off & Verbal process \\
\hline $42 b$ & it & happened & Material process \\
\hline 43a & I & see & Mental process \\
\hline $43 b$ & I & try & Material process \\
\hline $43 c$ & $\wedge \mathrm{I}$ & look away & Behavioural process \\
\hline 44 & More wars & /// & \\
\hline $45 a$ & The Americans & are installing & Material process \\
\hline $45 b$ & $\wedge$ The Americans & are invading & Material process \\
\hline $46 a$ & They & say & Verbal process \\
\hline $46 b$ & I & have acted & Relational process \\
\hline $47 a$ & I & don’t start & Material process \\
\hline $47 b$ & I & had & Relational process \\
\hline $47 \mathrm{c}$ & which (the only war) & was & Relational process \\
\hline $47 d$ & killings & would occur & Material process \\
\hline $47 e$ & $\wedge \mathrm{I}$ & disguised & Relational process \\
\hline $47 f$ & I & could do & Material process \\
\hline $47 g$ & all & was & Relational process \\
\hline 48 & I & could never drown & Material process \\
\hline 49 & $\begin{array}{l}\text { the beat of the bass } \\
\text { sounds of my } \\
\text { children's music }\end{array}$ & reminds... of & Mental process \\
\hline 50 & I & have & Relational process \\
\hline 51a & That & is & Relational process \\
\hline $51 b$ & I & can say & Verbal process \\
\hline
\end{tabular}




\section{Notes}

Note 1. There are no Existential processes in “Heroic Mother”. These examples are taken from Halliday's An Introduction to Functional Grammar, 2004, p. 171.

Note 2. http://www.hoapham.net

Note 3. More examples at Appendix B.

Note 4. More examples at Appendix C.

Note 5. More examples at Appendix D. 